Carlier, A., De Mulder, W. \& Lamiroy, B. 2012. The pace of grammaticalization in a Typological Perspective. Folia Linguistica, 2, 1-15.

\title{
Introduction: The pace of grammaticalization in a typological perspective
}

A grammaticalization process, by which an item shifts from lexicon to grammar, is by definition a cline or a continuum. Consequently, items undergoing grammaticalization processes can occupy different positions on the cline between its two extremes. The main claim we want to argue for in this thematic issue is that the same idea of gradation can be extended to language typology, by showing that, within a language family, comparable grammaticalization phenomena can be at the outset or on-going in one language and have reached a stage further down the cline in another language, or even that grammaticalization phenomena present in one language may be absent in the other one. Thus, with respect to Romance, several authors, such as Boysen (1966), Delattre (1966), Harris (1978), Posner (1996), Lamiroy (1999 and 2003), Marchello-Nizia (2006), Detges (2006), Carlier (2007) and Lindschouw (2010, 2011), have pointed out that for the majority of grammaticalization phenomena, French is further on the cline than the other Romance languages. Research on several independent domains, viz. word order (Marchello-Nizia 1995), prepositions (Lamiroy 2001), external possessor constructions (Lamiroy 2003), existential sentences (Meulleman, forthc.), tense, mood, demonstratives, auxiliaries (Lamiroy \& De Mulder 2011 and De Mulder \& Lamiroy, forthc.), the partitive (Carlier \& Lamiroy 2010), has furthermore shown that in most of these domains, Italian is ahead of Spanish, although the respective positions of Italian and Spanish on the cline seem to allow for more variability than the position of French. These studies suggest that with respect of the pace of grammaticalization, the three Romance languages can be situated on a scale in the following way.

\section{Hypothesis: the Grammaticalization Cline in Romance}

French > Italian > Spanish

Two short examples will show that French displays prototypical cases of grammaticalization that Italian and Spanish simply lack. First, the (late) Latin noun casa 'house' turned into a preposition in French, viz. chez (e.g. Les scientifiques ont constaté des aptitudes sociales chez les bonobos 'Scientists discovered social skills with the bonobo's'). In Spanish and Italian however, casa still exists as a noun and conserves its original meaning of 'house'. Similarly, the Latin noun homo 'man' underwent grammaticalization in French and became a personal indefinite pronoun, viz. on (e.g. On ne vit qu'une fois 'You live only once'). The grammaticalization of Latin homo is a clear case of "divergence" in Hopper's terminology, as the noun homme 'man' (derived from the accusative form hominem) also subsisted as an ordinary lexical item. In Spanish however, no indefinite pronoun developed out of homo: Spanish hombre up till now stayed as a noun which means 'man'. As to Italian, although homo initiated the grammaticalization cline towards the personal indefinite pronoun, perhaps due to French influence, this use became obsolete from the $16^{\text {th }} \mathrm{C}$. on and uomo in Modern Italian has only its original lexical value (Giacalone Ramat \& Sansò 2007).

The Hypothesis of the Grammaticalization Cline in Romance is not only supported by punctual instances of grammaticalization such as the above mentioned cases, but it also offers an insightful account of the specific evolution of several major morphosyntactic categories in French, Spanish and Italian, viz. verbal person, mood, tense and aspect and nominal gender and number. By way of illustration, we will evoke briefly the evolution of the use of the subjunctive mood in complement clauses from Latin to contemporary French, Spanish and Italian. The subjunctive originally expresses a value of non-factivity. Its use in complement clauses develops from early to classical Latin when paratactic structures progressively evolve into structures involving subordination. In subordinate clauses, the subjunctive is first used after main verbs expressing volition, doubt or uncertainty, where the subjunctive can be understood with its original value of non-factivity. Its use in subordinate clauses is thus originally motivated by the "harmony" between its intrinsic meaning and that of the 
main verb, as claimed by Bybee, Perkins \& Pagliuca (1994: 214, 221). However, since the main verbs (such as those expressing volition) already express the idea of non-factivity, the subjunctive can gradually lose its meaning and becomes a marker of subordination. Hence, it extends its use to other subordinate contexts (that do not convey the value of non-factivity), such as indirect questions. In the final stage of the grammaticalization path, once its use has spread significantly, the gram tends to be gradually lost from the language. At least three observations with respect to the conditions of use of the subjunctive in the three above mentioned Romance languages show that the French subjunctive is further down the grammaticalization path described by Bybee, Perkins \& Pagliuca (1994) than its Spanish and Italian counterparts:

(i) As has been pointed out in several recent studies (Lalaire 1998, Buridant 2000: 337, Loengarov 2006, Dreer 2007: 201, Lagerqvist 2009: 39, Lindschouw 2010, 2011, Jeppesen Kragh 2010), the French subjunctive declines in favor of the indicative, thus approaching the final stage of the grammaticalization path as described by Bybee, Perkins and Pagliuca (1994). For instance, in indirect interrogative clauses, where Latin used the subjunctive, French uses the indicative:
(1) Fr. Je ne sais pas quelle est/
*soit
la meilleure solution
I not know NEG what be- IND.PRS.3SG /be-SBJV.PRS.3SGthe best solution
'I don't know what the best solution is'

In the equivalent sentences in Spanish and Italian, on the contrary, both the indicative and the subjunctive are possible:
(2) It. Non so
quale è /
sia
la migliore soluzione
Not know-PRS.1SG
what be-
be-SBJ
$G$ the best solution
(3) Sp. No sé
cuál es
/sea
la mejor solución
Not know-PRS.1SG
what be-IND.PRS.3SG / be-SBJV.PRS.3SG the best solution

(ii) In contexts where French no longer allows mood choice, Spanish and Italian still do so, the subjunctive expressing non-commitment of the speaker. Thus, after verbs expressing 'hope', contemporary French clearly prefers the indicative, whereas both in Italian and Spanish either the indicative or the subjunctive are possible:
(4) Fr. J'espère
I hope
(5) Sp. Espero
que ma sœur
that my sister
viendra /
come-IND.FUT
que vendrá /
come-IND.FUT.3SG
venga
*vienne
Hope-PRS.1SG
that come-IND.FUT.3SG / cor
come-SBJV.PRS.3SG
Spero che verrá /
come-SBJV.PRS.3SG
(7) It.
Hope-PRS.1SG that come-IND.FUT.
'I hope that my sister will come'
venga
mi hermana
my sister
mia sorella

(iii) Moreover, in comparison with Spanish and Italian, French does no longer use the full range of forms: the subjunctive imperfect and the subjunctive past perfect have largely disappeared in modern French. This means that the French subjunctive has lost the temporal distinction between present and imperfect (e.g. que je chante / que je chantasse), on the one hand, and between present perfect and past perfect (e.g. que j'aie chanté / que j'eusse chanté), on the other hand, and has retained only the aspectual distinction between simple and compound forms (e.g. que je chante / que j'aie chanté).

The different conditions of use of the French subjunctive, in comparison with their Italian and Spanish counterparts can be accounted for by the Hypothesis of the Grammaticalization Cline in 
Romance, mentioned above: the evolution of verbal mood in French is ahead in comparison with Spanish and Italian. Interestingly, this hypothesis is further corroborated by the observation that the situation of contemporary Spanish and Italian frequently corresponds to that in Old French (for instance, in Old French, mood choice was possible after espérer 'hope', cf. Buridant 2000: 337).

With respect to the relation between Italian and Spanish in the Grammaticalization Cline in Romance, an important remark is in order with respect to Italian's regional variation : in Italian, there exists a tendency to replace the congiuntivo by the indicative in certain regions, mainly in the North, and especially in spoken language (Maiden \& Robustelli 2000: 327, Cardinaletti et al. 2001, Trifone \& Palermo 2007: 137); this suggests that Northern Italian might be starting a changing process of its mood system in a way analogous to what happened in French. Further evidence for this ongoing change in Italian is offered by Loengarov (2006: 195), who points out that some of his Italian informants use both the indicative and the subjunctive after certain verbs such as credere 'believe' and pensare 'think', but do no longer perceive a semantic difference between the two. At least for those users, the subjunctive may be losing its semantic value.

Although the above observations concerning the subjunctive provide convincing evidence for the aforementioned grammaticalization cline in Romance, as do most of the phenomena in the other domains mentioned above, it should be clear that the cline reflects a robust tendency, yet not an absolute rule, i.e. there may be phenomena that contradict it. Such a counter-example is offered by the selection of auxiliaries in the compound tenses of intransitive verbs: whereas French and Italian have two auxiliaries, être / essere and avoir / avere, Spanish has progressively extended, from the $16^{\text {th }}$ century on, the use of haber to all verbs, so that ser has eventually disappeared as an auxiliary of the compound tenses, being only used in verbal morphology as the auxiliary of the passive voice. Thus Spanish shows a higher degree of paradigmaticity (Lehmann 2002) in its auxiliary system than the other two Romance languages and should therefore be considered further down the cline than French and Italian. In our view, however, observations of this kind do not really challenge the Hypothesis of the Grammaticalization Cline in Romance, as they remain exceptional compared to an overwhelming majority of phenomena which point in the other direction.

This hypothesis with respect to Romance begs the question whether a comparable scale has been proposed for other language families. Interestingly, this turns out to be the case : for the Germanic languages, English has been shown to be further down most grammaticalization clines than Dutch and German - in that order (Hüning, Vogel, van der Wouden \& Verhagen 2006, König \& Gast 2007, Vismans, Hüning \& Weerman 2010).

A major question that remains to be answered, of course, is why languages show these differences in the pace of grammaticalization. A full answer to this question is not possible at the moment, as a series of both language internal and language external factors seem to be involved. With respect to language internal factors, it is largely recognized that French, in comparison with other Romance languages, shows in a more consistent way a double tendency:

- From a syntagmatic viewpoint, it tends to develop a pattern where the major grammatical categories - such as definiteness, gender, number in the nominal domain, or person, aspect, tense with respect to the verb - are consistently expressed by means of semi-autonomous, clitic or affixal items to the left of the head.

- From a paradigmatic viewpoint, these major grammatical categories tend to be marked by means of expressions belonging to tightly integrated paradigms, consisting of a small set of members linked to each other by clear-cut paradigmatic relations (Lehmann 2002: 118).

Insofar as language change tends to typological consistency (Lehmann 1973, Harris 1984), it can be hypothesized that the frequent use of the above mentioned pattern and the strong tendency 
towards paradigmatization entailed a kind of "snowball-effect" and, may have led, more than in other Romance languages, to the development of similar tightly integrated paradigms (for comparable ideas, cf. Bybee 2010, Hopper \& Traugott 2003:128, Marchello-Nizia 1995: 168, Krug 2000). Hence, the faster pace of grammaticalization of French seems to be correlated to the fact that French, more than other Romance languages, has restructured its grammatical macro-system, an idea that has been illustrated, amongst others, by Marchello-Nizia $(1995,2003,2006)$ in her analyses of the evolution of word order, demonstratives and indefinite morphemes in French. However, as convincingly argued in the literature (Milroy \& Milroy 1985, Trudgill 2010, 2011, Lupyan \& Dale 2010, Dale \& Lupyan 2011, Weerman 2006), the rhythm of language change - including that of grammaticalization processes - also hinges on social and demographic factors. According to these researchers, the more languages spread over large populations and involve frequent language contact between individuals who are related to each other by weak ties (in terms of family relations or parameters such as having the same profession, spending leisure time in the same way, living in the same neighborhood, etc.), the faster languages may evolve by regularizing mechanisms, ultimately also reducing their morphological and grammatical systems. However, as pointed out by Trudgill (2011), these factors do not determine the rate of language change in the strong sense, as one also needs to take into account the interaction between them. Moreover, external factors presumably mainly concern later stages of the grammaticalisation process, i.e. when changes spread across the language, rather than the initial and more innovative phase; as the initial phase involves complexification due to the introduction of new (and competing) forms, it may display a rather slow rate of change. Finally, the question should be raised how exactly external and internal factors interact and whether, for instance, external factors played a decisive role in the fact that may explain why the French grammatical macro-system has undergone such a more radical restructuring than that of the other Romance languages.

The contributions to the present issue of Folia will not dwell upon the crucial question of why languages grammaticalize at a different pace, though. Adopting a broad definition of grammaticalization, as, e.g., "the gradual drift in all parts of the grammar toward tighter structures, toward less freedom in the use of linguistic expressions at all levels" (Haspelmath 1998: 318), their main aim is to further test the Hypothesis of the Grammaticalization Cline in Romance by (i) looking into other grammaticalization phenomena than those hitherto analyzed and (ii) by searching evidence in Romance languages other than French, Italian and Spanish.

The paper of Karen Lahousse and Béatrice Lamiroy is devoted to word order in French, Spanish and Italian and largely confirms the Hypothesis of the Grammaticalization Cline in Romance, central in this issue. The first section deals with word order patterns in general. Whereas Spanish allows all word order patterns but SOV (i.e. SVO, VOS, OSV, VSO and OVS), Italian lacks SOV and VSO, and French moreover lacks SOV, VSO and OVS. These differences are accounted for in terms of grammaticalization: word order is highly grammaticalized in French, weakly grammaticalized in Spanish, whereas Italian occupies an intermediate position. The second section focuses on VOS, allowed by the three Romance languages under study, and examines in which discourse contexts this pattern can be used. Again, it is pointed out that the constraints on VOS constraints are the strongest in French and the weakest in Spanish. Independent evidence for this claim is provided by a study of cleft structures, which have the same function as VOS with respect to information structure. Not surprisingly, it is most developed in French, least in Spanish, while it is progressing in Italian.

loanna Sitaridou's article also deals with word order phenomena, but extends the languages under consideration to Old Romance. The position of the verb is examined from a generative and comparative perspective, viz. in Old French, Old Occitan, Old Portuguese and Old Spanish. In the generative literature, Old Romance languages are regarded as V2-languages, whereas Modern 
Romance languages are considered to have lost this property, i.e. both the ability of the verb to reach as high as the $\mathrm{C}$ (omplementizer) head as well as the obligatory fronting of a constituent. However, this view has been recently challenged - among other reasons - because Old Romance allows structures which are not compatible with a V2-grammar. By means of a statistical analysis of novel data it is claimed here that: (i) Old Romance does not possess a Germanic V2; (ii) there is variation among Old Romance which is shown to be linked to the individual history of the languages; (iii) V2 order is mostly an epiphenomenon due to special discourse mechanisms and to the nature of the left functional field in these languages.

The aim of Machteld Meulleman's contribution is to investigate whether and to what extent the hypothesis of French being more grammaticalized than any of the other Romance languages applies to existential constructions. The study is based on a large newspaper corpus in the three languages involved in the Hypothesis of the Grammaticalization Cline in Romance mentioned above. In all three languages, the existentials, viz. il y $a, c^{\prime}$ è and hay respectively, are highly grammaticalized expressions. A detailed analysis of the data in terms of Lehmann's (1995-2002) parameters of grammaticalization however shows that - as expected - French existential constructions display several signs of a highly advanced grammaticalization stage which their Spanish and Italian counterparts lack. However, the Spanish existential construction which corresponds to an impersonal verb, with a high degree of agglutination ( $h a y=h a+y$ ), is further grammaticalized than its Italian equivalent esserci that still agrees with a singular (c'è) or a plural (ci sono) subject.

Augusto Soares da Silva's contribution is a comparative analysis of causative verbs and causative constructions in Portuguese, Spanish, French and Italian. In all four languages, they are analyzed in terms of degrees of grammaticalization with respect to four parameters, viz. semantic bleaching, event integration, subjectification and the possibility of certain construal operations. Portuguese and Spanish, compared to French and Italian, show less grammaticalization because they have (next to a monoclausal VV structure) a bi-clausal VOV causative structure that no longer exist in French or Italian. The existence of the inflected infinitive in Portuguese (in VSV structures) makes Portuguese causative constructions even less integrated than Spanish ones. The results of this study show a decreasing continuum of grammaticalization of causative constructions in Romance languages that starts with Italian, goes on to French, then Spanish and finally Portuguese. Two different types of additional evidence for the grammaticalization cline of Romance causative constructions are briefly provided, namely onomasiological evidence and diachronic evidence.

The paper by Claudio lacobini is devoted to the various ways in which Romance languages encode motion events, following Talmy's (1996) model of Verb-Framed vs. Satellite-Framed languages. Although the general evolution from Latin to Romance involves a transition from a Satellite-Framed to a Verb-Framed type, the expression of motion events varies according to the individual Romance language, both from a typological and a diachronic point of view. Thus Italian still displays a larger number of Satellite-Framed features than Spanish and French. In line with Herslund's (2005) analysis, lacobini presents the history of encoding motion events in Romance as a chain of grammaticalization processes on a three-stage evolutionary scale, going from a low to a high degree of grammaticalization. Current French is shown to be the only Romance language which displays features of the third-scale level, thus confirming the central hypothesis here of French being in many linguistic domains further grammaticalized than the other Romance languages. The author also examines other factors which may account for the typological change from the Satellite to the VerbFramed type in Romance, such as the psycholinguistic difficulty of processing boundary-crossing motion events. 
Benjamin Fagard \& Alexandru Mardale illustrate the uneven pace of grammaticalization in Romance by an analysis of the simple and complex prepositions in present-day French, Italian, Portuguese, Romanian and Spanish. They check the validity of existing lists against written and spoken corpora, and evaluate the degree of grammaticalization of prepositions and postpositions, mainly on the basis of morpho-syntactic criteria and by taking into account these items' frequencies (Bybee 2006). Their analysis results in a clear picture of the degree of grammaticalization of prepositions in present-day Romance, which confirms that French is further down the grammaticalization clines involved than Italian, Spanish, Portuguese and Romanian.

Marleen Van Peteghem's paper deals with possessives in French, Italian, Spanish and Romanian and considers three types of possessives: adjectives, determiners and pronouns. The evolution from Latin to the four present-day Romance languages under study exhibits two common tendencies: (i) possessive pronouns tend to be eliminated, and (ii) possessive adjectives change into determiners or become deficient adjectives with a restricted distribution. The differences with respect to the possessive paradigm in the different Romance languages can be conceived as different degrees of grammaticalization: the grammaticalization of the possessive paradigm is most grammaticalized in French, for two crucial reasons: (i) the determiner is a clitic and (ii) the strong possessive form no longer displays an adjectival distribution. The least grammaticalized possessive paradigm is the Italian, because it is still highly adjectival. Spanish occupies an intermediate position, since it is endowed with a double system: a clitic determiner, similar to French, and a strong possessive, similar to Italian. The comparison of the Rumanian possessive with that of the other Romance languages is more delicate since it exhibits some peculiarities, due to the fact that Rumanian has a case inflection, and that it followed a totally different evolutionary path. The possessive has nevertheless less adjectivelike features than the Italian possessive or the Spanish strong possessive.

Michael Herslund's paper, which is devoted to the evolution of the indefinite article, confirms French to be more grammaticalized than Spanish in this domain. Whereas all West-European languages have developed an indefinite article from the numeral 'one', not all nouns in all languages accept this article, and most languages do not have an indefinite article in the plural. Herslund accounts for the distribution of the indefinite article in the different languages by examining the origin of the indefinite article and its different grammaticalization patterns resulting from the interpretation of the unity numeral as either a quantifier, or a classifier or both:

1. The indefinite article functions as a quantifier in the Germanic languages which exhibit a basic lexical classification of nouns into mass and entity denoting nouns; there is no indefinite article with singular mass nouns, neither with plural nouns.

2. The indefinite article acts as a classifier in Modern French, where two different forms of the indefinite article occur with all nouns, in the singular as well as in the plural. The two perform a lexical classification at phrase level.

3. A mixed system is found in Old French and Spanish, where there is no general indefinite article in the plural, but a collective indefinite article. The bare plural is identical to the bare singular (mass interpretation), and the collective plural is identical to the articulated singular entity.

Anna Giacalone and Catarina Mauri compare the diachronic processes leading to contrastive connectives in Romance languages. Their data also confirm that French has a faster pace, French contrastive connectives being the most innovative in comparison with the other Romance languages. Although they agree that the search for explanations can be only speculative, they mention as a first factor the high degree of differentiation characteristic of spoken Latin, which lead to the different varieties of Latin spoken in Gaul and elsewhere. The Latin that was spoken in the empire in the first centuries of our Era seems to have been the source of many innovations (Banniard 1992, Cennamo 2008), as clearly appears in the case of adversative connectives, for which Latin itself offered the 
lexical sources of renovation (dum interim, tota via, per hoc, per tantum). Another possible reason for the faster pace of grammaticalization in French would reside in language contact: according to Hopper and Traugott (2003: 212), a situation of intense and long contact with bilingualism may result in the emergence of new constructions (not necessarily replicated from one of the languages in contact: Heine and Kuteva 2005) and in the restructuring of particular grammatical areas. Adopting data and insights from Matras (1998: 301-305), the authors show that adversative connectives are crucial to the expressive potential of speakers, especially in situations of intense language contact, as was the case at the time Old French developed. Consequently, this might be the ground for the higher rate of innovation in adversative connectives in French and possibly also for its faster pace of grammaticalization.

The final paper by Maj-Britt Mosegaard Hansen and Jacqueline Visconti offers a comparative analysis of the evolution of negation in French and Italian, with reference to the negation cycle first noticed by Jespersen, and considers both standard clause negation (Fr. ne ... pas, It. non) and $n$-word negation (e.g. Fr. (ne)... personne, It non ... nessuno 'nobody'). As to the clause negation, it is argued that its grammaticalization is far more advanced and also more "linear" in French than in Italian. Conversely, $n$-word negation is shown to have developed more gradually (and to be still developing), but, interestingly, once again more linearly in French than in Italian. French offers an almost perfect illustration of Jespersen's negation cycle, whereas the different stages of the evolution in Italian are far from neatly ordered. The analysis offered in the paper suggests that the pace and form of grammaticalization cannot be attributed to any single cause (phonetic erosion for instance), but is rather the result of an interplay of formal and functional factors.

As a conclusion, it can be said that most contributions confirm the Hypothesis of the Grammaticalization Cline in Romance and extend it, at least for some phenomena, to other languages. At least with respect to the phenomena under study in the relevant papers contained in this issue, Portuguese seems to be even "less grammaticalized" than Spanish. As for Romanian, it seems difficult to determine its exact position with respect to the other languages, since it has some characteristics that assign it a separate place (such as the maintenance of its case-system). Moreover, it should be pointed out, in general, that whereas the position of French as being the language that has gone furthest down the clines, seems generally accepted, the exact order of the other languages on the cline is more liable to variation. This is particularly shown here in the papers by lacobini and Van Peteghem. However, we ultimately invite the reader to discover this volume and to judge by himself to what extent the Hypothesis of the Grammaticalization Cline in Romance is justified.

Anne Carlier, Walter De Mulder and Béatrice Lamiroy

\section{References}

Banniard, Michel (1992). Viva Voce. Communication écrite et communication orale du IVe au IXe siècle en Occident latin. Paris: Institut des Etudes Augustiniennes.

Boysen, Gerhard (1966). L'emploi du subjonctif dans I'histoire des langues romanes. Bulletin des Jeunes Romanistes 13: 19-33.

Buridant, Claude (2000). Grammaire nouvelle de l'ancien français. Paris: SEDES.

Bybee, Joan, Revere Perkins \& William Pagliuca (1994). The Evolution of Grammar. Tense, Aspect and Modality in the Languages of the World. Chicago: The University Press of Chicago.

Cardinaletti, Alesi, Giampaolo Salvi \& Lorenzo Renzi (2001). Grande grammatica di consultazione. Bologna: II Mulino.

Bybee, Joan (2006). From usage to grammar: The mind's response to repetition. Language 82/4, 711-733.

Bybee, Joan (2010). Language, Usage and Cognition. Cambridge : Cambridge University Press. 
Carlier, Anne (2007). From preposition to article : the development of the French partitive. Studies in Language 31:1, 1-49.

Carlier, Anne \& Béatrice Lamiroy (2010). The grammaticalization of the partitive. Paper presented at SLE Conference, Vilnius, 2 -5 September 2010.

Cennamo, Michela (2008). The rise and development of analytic perfects in Italo-Romance. In Thórhallur Eythórsson, ed. Grammatical Change and Linguistic Theory, 115-142. Amsterdam: Benjamins.

Dale, Rick \& Gary Lupyan (in press). Understanding the origins of morphological diversity: the linguistic niche hypothesis. Advances in Complex Systems (special issue on language dynamics)

Delattre, Pierre (1966). Stages of Old French phonetic changes observed in Modern Spanish. In Studies in French and Comparative Phonetics: Selected Papers in French and English, 175-205. The Hague: Mouton and Co.

Detges, Ulrich (2006). The passé composé in Old French and the Old Spanish perfecto compuesto. In Change in Verbal Systems. Issues on Explanation, Kerstin Eksell \& Thora Vinther (eds), 47-71. Berlin: Peter Lang.

Dreer, Igor (2007). Expressing the Same by the Different. The Subjunctive vs the Indicative in French. Amsterdam: John Benjamins.

Harris, Martin (1978). The Evolution of French Syntax: A Comparative Approach. London: Longman.

Harris, Martin (1984). On the causes of word order change. Lingua, 63:2, 175-204.

Haspelmath, Martin (1998). Does grammaticalization need reanalysis? Studies in Language 22: 315-351.

Herslund, Michael (2005). Lingue endocentriche e lingue esocentriche: aspetti storici del lessico. In Iørn Korzen, Carla Marello, eds., Tipologia linguistica e società. Firenze: Franco Cesati, 19-30.

Hopper, Paul \& Elizabeth Traugott (2003). Grammaticalization. Cambridge: Cambridge University Press.

Hüning, Matthias, Ulrike Vogl, Ton van der Wouden \& Arie Verhagen, eds (2006). Nederlands tussen Duits en Engels. Leiden: Stichting Neerlandistiek Leiden.

Giacalone Ramat, Anna \& Andrea Sansò (2007). The indefinite usage of uomo 'man' in early Italo-Romance: grammaticalization and areality. Archivio glottologico italiano, XCII: 65-111.

Jeppesen Kragh, Kirsten (2010). Le remplacement de l'imparfait du subjonctif par le présent du subjonctif considéré dans une perspective de grammaticalisation. Copenhague: Museum Tusculanum Press.

König, Ekkehard \& Volker Gast (2007). Understanding English-German Contrasts. Berlin : Erich Schmidt Verlag.

Krug, Manfred (2000). Emerging English Modals. A Corpus-Based Study of Grammaticalization. Berlin / New York: Mouton de Gruyter.

Lagerqvist, Hans (2009). Le subjonctif en français moderne. Paris: Presses de l'Université Paris-Sorbonne.

Lalaire, Louis (1998). La variation modale dans les subordonnées à temps fini du français moderne. Bern: Peter Lang.

Lamiroy, Béatrice (1999). Auxiliaires, langues romanes et grammaticalisation, Langages 135. 33-45.

Lamiroy, Béatrice (2001). Le syntagme prépositionnel en français et en espagnol: une question de grammaticalisation? Langages 143, 91-106.

Lamiroy, Béatrice (2003). Grammaticalisation et comparaison de langues. Verbum 25: 411-431.

Lamiroy, Béatrice \& Walter De Mulder (2011). Degrees of grammaticalization across languages. In Narrog, H. \& Heine, B. (eds). The Oxford Handbook of Grammaticalization. Oxford: Oxford University Press.

De Mulder, Walter \& Béatrice Lamiroy. forthc. Gradualness of grammaticalization in Romance. The position of French, Spanish and Italian. In Breban, T., Brems, L., Davidse, K. and Mortelmans, T. (eds) New theoretical perspectives on grammaticalization and other processes of change: origins, recognition criteria and outcomes Amsterdam: John Benjamins (in press).

Lehmann, Winfred P. (1973). A structural principle of language and its implications. Language 49, 47-66.

Lehmann, Christian (2002). Thoughts on Grammaticalization. Second revised edition. Available at <http://www.christianlehmann.eu/>.

Lindschouw, Jan (2010). Grammaticalization and language comparison in the Romance mood system. In EvaMaria Remberger \& Margin G. Becker, eds. Modality and Mood in Romance. Modal Interpretation, Mood Selection, and Mood Alternation, Berlin: Walter de Gruyter, 181-207.

Lindschouw, Jan (2011). Etude des modes dans le système concessif en français du $16^{e}$ au $20^{e}$ siècle et en espagnol moderne: Evolution, Assertion et Grammaticalisation. Copenhagen: Museum Tusculanum Press.

Loengarov, Alexander (2006). L'alternance indicatif / subjonctif dans les langues romanes. Motivation sémantico-pragmatique et grammaticalisation. Ph.D. Dissertation, University of Leuven.

Lupyan, Gary \& Rick Dale (2010). Language structure is partly determined by social structure. Plos One 5: 1-10.

Maiden, Martin \& Cecilia Robustelli (2000). A Reference Grammar of Modern Italian. London: Arnold. 
Marchello-Nizia, Christiane (1995). L'évolution du Français. Ordre des mots, démonstratifs, accent tonique. Paris: Armand Colin.

Marchello-Nizia, Christiane (2003). Changes in the structure of grammatical systems : the evolution of French. Forum for Modern Language Studies 39 / 4 : 371- 385.

Marchello-Nizia, Christiane (2006). Grammaticalisation et changement linguistique. Bruxelles : De Boeck.

Matras, Yaron (1998). Utterance modifiers and universals of grammatical borrowing. Linguistics 36-2: 281-331.

Meulleman, Machteld. forthc. Les localisateurs dans les constructions existentielles. Approche comparée en espagnol, en français et en italien. Tübingen: Niemeyer.

Milroy, James \& Lesley Milroy (1985). Linguistic change, social network and speaker innovation. Journal of Linguistics 21: 339-384.

Posner, Rebecca (1996). The Romance Languages. Cambridge: Cambridge University Press.

Talmy, Leonard (2006). The fundamental system of spatial schemas in language. In B. Hampe, ed. From perception to meaning: Image Schemas in Cognitive Linguistics. Berlin: Mouton de Gruyter 199-234.

Traugott, Elizabeth C. \& Graeme Trousdale (2010). Gradience, gradualness and grammaticalization: how do they intersect? In E. C. Traugott \& G. Trousdale, eds. Gradience, Gradualness and Grammaticalization, Amsterdam: John Benjamins, 19-44.

Trudgill, Peter (2010). Contact and sociolinguistic typology. In The Handbook of Language Contact, R. Hickey (ed.), 299-319. Oxford: Wiley-Blackwell.

Trudgill, Peter (2011). Sociolinguistic typology. Social Determinants of Linguistic Complexity. Oxford: Oxford University Press.

Vismans, Roel, Matthias Huening \& Fred Weerman (eds.) (2010). Dutch between English and German, Special issue of Journal of Germanic Linguistics, 22.

Weerman, Fred (2006). 'It's the economy, stupid! Een vergelijkende blik op men en man', in M. Hüning, U. Vogel, T. van der Wouden \& A. Verhagen (eds). Nederlands tussen Duits en Engels. Leiden: SNL, p. 19-47.

Wichmann, Søren \& Eric Holman (2009). Population size and rates of language change. Human Biology 81: 259274. 